\title{
Once More on the Notion of the Unit of Translation
}

\author{
Olga I. Brodovich* \\ Institute of Foreign Languages \\ 13, 12 Linija, Vasilievsky Island, St. Petersburg, 199178, Russia
}

Received 16.11.2014, received in revised form 14.12.2014, accepted 23.01.2015

\begin{abstract}
The paper has two main goals. Firstly, it is aimed at proving that there is a single principle governing the choice of any portion of the original - from morpheme to the entire text-for the role of the unit of translation (UT). It is based on the role a linguistic unit plays in the bigger form of which it is an integral part. If it makes its individual input into the meaning of the whole then it should be given special attention in translation, i.e. at some stage of re-coding made a UT. But if the meaning of the whole larger construction is such that it is not made up by putting together the meanings of its composite pars - a situation termed idiomatic - then (and only then) the entire whole is taken as a unit of translation. The paper also shows that when theorists declare that there is only one linguistic entity which can be qualified as a UT-in some works this is the sentence, in others, the entire text-they are using the term in their own interpretation and not in the meaning that was give the term by its authors. But it is essential for any theory that its terms, in the case discussed - the term 'unit of translation' - be applied by all in one and the same meaning, and exactly in the meaning that was given it at inception. Because the UT was defined as a portion of the original text, it would seem that the text as a whole cannot serve as a UT. The second aim of the paper, however, is to show that there are certain types of texts that answer the same requirements for serving as a UT that are valid for all other linguistic units. These are poetical texts of such fineness that places them onto their own highest level of linguistic structures. It is these texts that for purposes of re-coding demand being taken as a whole, i.e. as an undivided unit of translation.
\end{abstract}

Keywords: unit of translation, variability, the translator's choice, linguistic units with idiomatic properties, translation of poetry, text as a unit of translation.

Research area: philology.

\section{Introduction}

The term Unit of Translation (UT) is not universally accepted by translation theorists mainly (though not solely) because of its indefinite relations to other linguistic units. The present author shares the belief of J.P.Vinay and J Darbelnet (Vinay, Darbelnet, 1965) in the existence of the UT and fully agrees with W.Haas
(Haas, 1968) that it should be as short as possible and as long as is necessary. The should in this formula is significant. It shows that materially the UT is a variable depending on the translator's choice. In works where the UT is discussed its size is shown to fluctuate between a phoneme or grapheme and an entire text. All of this is wellknown to translation theorists, even to those

(C) Siberian Federal University. All rights reserved

* Corresponding author E-mail address: olgabrodovich@yandex.ru 
who deny either the existence of the UT or the usefulness of the term. What has seldom if ever been seriously discussed is the reason for choosing a particular fragment of the ST as a UT. It is not that the question has never been asked. Far from it - the choice of one or another linguistic form for a particular act of translation has been commented upon for various particular cases in practically all textbooks on translation. Even in works where no mention is made of the term, the authors always seriously analyse the size of the stretches of the SL text to be taken as an object for immediate recoding operations. But the quest for the general considerations for the translator's choice relevant for all and every act of such decisions has so far - to the author's belief - not been considered possible in view of the obvious variability of the UT. The aim of the present paper is twofold: (a) to show that the question of predictability of the choice must and can be asked and answered and (b) to show that the choice of the entire text for the UT, rare as it is in practice, is also predictable on the same grounds as the choice of other units of translation.

\section{Phoneme/grapheme as a UT}

We will begin with the choice of a phoneme/ grapheme as a UT because here the grounds are essentially different than in the cases of all larger units. On the face of it these entities cannot be taken as tools for re-coding the original message because translation is aimed at rendering the meaning of the SL text, while phonemes and graphemes are purely functional entities devoid of any semantic meaning. Yet, as is well known, using a phoneme or grapheme for translating, viz. using transcription/transliteration as a translation technique, is justifiable and even sometimes recommended - for a limited number of very specific ST portions. These are proper names, realia and some types of terminological items. Phonemes or graphemes as unilateral entities with only the form and no meaning are the right choice for rendering portions of the SL text with similar properties, that is, for lexemes in the ST which have a sound-shape but no meaning in the general sense of the word, or with meanings unknown in the recipient culture. Indeed, we can say (slightly idealizing and generalizing the situation) that proper names, to use St.Ullman's terminology, identify but do not signify (Ullman, 1967: 73); realia are words naming cultural phenomena unknown outside the world of the SL culture, therefore these words have no meaning for people of another culture, i.e., for readers of the TL text; in most cases newly coined terms are, for all practical purposes, realia come from the world of science. They all have their sound-shape and - for the reader of the TL - only that, so this is what the translator, resorting to transcription or transliteration, reflects in her/his TL text. True, for transcribed (transliterated) realia or new terms the translator will have to supply some comments as to the meaning of the resulting new word, but this is only the consequence of the choice of the UT and not the action itself.

It should also be noted that because the form resulting from translation/transliteration is indeed a pure form with no lexical meaning (note, however, that it is so only unless and until such word is accepted by the TL as a loan word), many linguists, including, sadly enough, some of translation theorists (see, for example, Vlakhov, Florin, 1986: 96-105), put this operation outside the scope of translation proper. We often read statements like"somesuch terms were transcribed, others translated". But because the operation of transcription was applied by the translator it is, of course, a fact of translation, an act of the choice by the translator of the minimal UT. Transcription and transliteration are legitimate translation operations, provided, of course, that the translator correctly identified a particular word as an item needing this operation. 


\section{Bilateral linguistic units taken as UT}

We now turn to bilateral, i.e. meaningful linguistic units in their function as UT. Here we must draw a line between the word on the one hand and all other entities, from morpheme to text, on the other.

The word alone needs no justification for being used as the UT. The word is an ideal tool for segmentation of reality into fragments to be identified, distinguished and consequently named. In spite of all the cultural differences that are discussed as sources for untranslatability, different nations in building their vocabularies find similar items for identification and naming far more often than items that become specific to a particular language, and this is proved by the very existence of bilingual dictionaries. True, in view of the role that S.Karcevski's asymmetry plays in bilingual situations, which, moreover, is augmented by linguoethnical peculiarities of the two languages, word-by-word translations, where the choice of a word for the UT is obvious, seldom receive the status of final decisions of a translator. The translator more often than not is forced to resort to all kinds of transformations, including lexical transformations, so that in the resulting version of the translation the original use of the word as the operational unit can seldom be traced - but because of the linearity of discourse words always form the base of the first stage of the decoding process. See, for example, a very illuminating argumentation on this point in chapter 5 of (Vinogradov, 2001), especially p.3133 - although the author never applies the notion of the UT.

Special attention should be paid to the interplay of the word with its context or, rather, to how it is treated in books on translation. For instance, we sometimes read that in examples like $\mathrm{Oн}$ жил в Петербурге $\rightarrow \mathrm{He}$ lived in St.Petersburg the word жил was used - correctly - as the UT and rendered by the corresponding English word lived, whereas in sentences like $О н$ жил в Астории the word жил cannot be used as the UT because in this context it has another meaning and another English analogue, viz. stayed (He stayed in the Astoria hotel). Here the UT is said to be not a word but a word combination, in this case, жил plus the name of a hotel. But the correspondence of жил to the English lived in the first sentence is also the result of the word жил being placed in that particular context, viz. жил plus the name of a town. The meaning of a word is always a function of its context. In the example discussed the translation of Он жил в Астории $\rightarrow$ He stayed in the Astoria hotel the item жил was used as the UT just as it was done for $\mathrm{OH}$ жил в Петербурге. Estimation of the phrase жил в Астории as the minimal stretch of the text taken as a UT, was evidently done on the silent assumption that the only occasion when a separate word is taken as a UT is the case when the word appears in its so-called first meaning (i.e. the meaning mentioned first in dictionaries because it is the most frequently used one), while taking account of any other meaning is an act of a translator's inventiveness and demonstrates the choice of a larger UT. Because there is no such thing as a context-free meaning of a word such assumptions are erroneous. Interestingly, sometimes it is not the literal and therefore historically first meaning of a word which at present is appreciated as its so-called first meaning. Thus the first meaning of the word to misread is shown by the COBUILD dictionary to be 'to misunderstand someone's behaviour' and only the second meaning is connected with something that is written. One wonders which of the following two examples would be taken as needing the word to misread as a UT and which one would supposedly need for this aim the combination of the verb with 
its object: 'She had misread a date in the Tour Book' or 'He was unconsciously misreading their actions'?

Let us now pass to other linguistic items in their potential role of the UT. We will begin with the smallest of them, the morpheme.

Here there is an important difference between inflexions and derivational affixes. Contrary to what is sometimes stated in the literature, the meanings of inflexions are not always rendered in the resulting translation. They are either translated only partially, or completely ignored.

There is an important difference here between endings with semantic meaning, like the meaning of case, and purely syntactical 'meanings' like, for example, those of person, number and gender of a verb. Consider translating the Russian ending -ов in words like волков, облаков, etc. into a language like English, in whose grammar there is no category of either case or gender of nouns. A translator into English can and must reflect the plurality of the noun in question - there are special morphemes in English to do that. But the rest of the information contained in the inflection will have to be differently treated. The meaning of the case (both in formal and semantic interpretations of the term) cannot be rendered by a special discreet device: there simply isn't any such device in English. However, the translator does reflect the function of the word indicated by the ending by placing its English analogue in the suitable position in the sentence and, if necessary, introducing a preposition. But the 'meaning' of the gender (in this case masculine or neutral) will simply have to be ignored.

A similar situation is demonstrated by inflections such as personal endings of Russian verbs: работают, рисовала, думали, etc. The tense component in the meaning of these endings will, of course, be reflected in an English translation, but other components - the indication of number, person or gender - will be ignored with no detriment to the resulting text.

Thus, if a grammatical category of an inflexion in the SL does exist in the TL grammar, it can and in most cases will be reflected in the translation. But where items of the SL grammar have no isomorphic correspondents in the TL grammar, there is a difference between the cases when such items are meaningful for the text translated, in that they show the role of the word in the sentence, and the cases where semantically they are meaningless, performing the purely formal function of syntactic coordination. Meanings of the first type are reflected using suitable tools of the TL grammar. 'Meanings' of the second type are simply ignored. What is important to realize, though, is that in none of these cases is a morpheme in question taken as a UT separately from the rest of the word containing it.

The nature of derivational affixes is different. They change the lexical meaning of the root word and, of course, cannot be ignored. But in the majority of cases the meaning of a resulting polymorphic word in its relation to the meanings of its component morphemes is exactly the same as in an idiom as defined by the WEUD, namely "an expression whose meaning is not predictable from the usual meanings of its constituent elements" (WEUD: 707, s.v. idiom). Speaking about English words containing suffixes, I.V.Arnold specially mentions this feature: “... suffixes are as a rule semantically fused with the stem ..." (Arnold, 1986: 80). This means that in translations it is the entire stem+suffix combination - i.e. the word, and not its constituent parts, the morphemes - would as a rule be chosen as a UT. Cf., for example, big, soulful eyes $\rightarrow$ большие выразительные глаза; 'Now then', she cried heartily, 'who's for a drink?' $\rightarrow H y$, - весело закричала она,кто хочет выпить?; He is only moody because 
things are not working out at home $\rightarrow O H$ мрачный просто потому, что дома не все в порядке; These bungalows were built in 1946 to ease the housing shortage after the last war $\rightarrow$ Эти постройки были возведены в 1946 году, чтобы уменьшить нехватку жилья, образовавшуюся после войны. If, however, the meaning of a suffigated word is not idiomatic with respect to the meanings of its component parts, the root and the suffix will have to be both reflected in the translation, as in birdie $\rightarrow$ птичка; doggie $\rightarrow$ собачка; motherless $\rightarrow$ лишенный матери; motherlike $\rightarrow$ (поведение, поступок) подобающий матери.

In contrast to suffixes, “... prefixes ... remain semantically rather independent of the stem" (Arnold, ibid.). This suggests the idea that English prefixes should be translated as separate members of the semantic whole of the word. And indeed, for many cases this will hold true, as interrelations $\rightarrow$ взаимоотночения, ипрremeditated $\rightarrow$ непредумышленный. See, however intercourse $\rightarrow$ общение, unadulterated $\rightarrow$ настоящий, цельный as in цельное молоко, mistake $\rightarrow$ ошибка, where the words in Russian translations are not composed of Russian analogues of respective English morphemes. In these cases the meanings of the words with prefixes is not the mechanical sum of the meanings of the composite morphemes. The stem course, for example, taken as a separate word never has the meaning of a personal contact of any kind. The meanings of 'communication between two people'; 'the act of having sex' (COBUILD, s.v. intercourse) belong only to the fusion of inter + course. So we see that where the word is idiomatic with respect to the meanings of its constituent morphemes it is translated as a whole thus serving as a UT. But where it is not so, i.e. where each of the morphemes of a polymorphic word gives its separate input into the meaning of the whole, it is the morpheme and not the word that will be taken as the minimal fragment of the SL text to be reflected in the translation, i.e. as the UT.

From the units smaller than a word we pass now to units larger than a word. We will begin with a word group. We have seen with regard to examples where a word is used in one of its secondary meanings that these cases are taken by some theorists to illustrate instances of a UT larger than a word. We have also seen that as a general rule the meaning of a word, whether primary or secondary, is a function of its context, therefore these assumptions are mistaken. But in some cases the meaning of a word combination is such that it "is not obvious from the words contained in it" (COBUILD, s.v. phrase). In English terminology these instances are termed a phrase (COBUILD) or an idiom (WEUD). Russian linguists devote to the study of these cases a special branch of linguistics, viz. фразеология. (The meaning of the English word phraseology has no value of 'a branch of learning'.) It is these contexts which demand the choice of the whole phrase to serve as a UT.

Another instance of a whole word group to be jointly taken as a UT is when this group of words is a standard description of a single object, for which other languages may, naturally enough, have a one-word term. Thus the Russian term военно-морской флот (военно-морские силы), which is a phrase, corresponds to the English single-word term Navy; reversely, the English two-word name phrase book corresponds to the Russian word разговорник. These expressions are similar to phrases, or idioms in that the words contained in them are fixed and are not interchangeable with their synonyms; they are also semantically indivisible, because they jointly give a description of a single object.

Thus we see that a whole phrase may be taken as a UT, but only when it is a semantic 
unity allowing no variation of the words composing it. Only these cases answer the definition of the UT given to it by the authors of the term.

Structural units that are larger than word groups, or phrases, are sentences. Some theorists contend that the sentence is the only correctly identified UT, for it is not before the whole sentence is translated can one appreciate the adequacy of individual efforts of the translator. Although the role of the whole in appraising the qualities of the constituent parts is indisputable, the above contention goes contrary to the original definition of the UT as given by the authors of the term, namely, that it is, to use Peter Newmark's translation from the French, "the smallest fragment of an utterance whose cohesion of signs is such that they must not be separately translated" (Newmark, 1988: 54). Indeed, if one wants one's theory to be understood by all, it is advisable to use terms in the meanings they were given at inception and which were then accepted by the professional public. Because in dealing with a normal sentence the translator begins with words or sometimes other fragments discussed above, the sentence is practically never taken as a UT.

However, some types of sentences can and, indeed, must be used in this function. It concerns only the sentences which are semantically indivisible into smaller parts. This answers the description of idiomatic expressions discussed above. The methods of coping with these types of sentences are well known. It only remains for us to mention that there also is another type of sentences which are translated as an integral whole. They are standard informational phrases like Wet paint!, Staff only, Trespassers will be prosecuted, etc. Although semantically these sentences mean exactly what their words say, their pragmatic meaning depends on their wording to be invariable, for they are intended for immediate recognition and automatic reaction of the reader. Their pragmatic indivisibility makes them analogous to idioms, preventing the translator from splitting them into separate words for the re-coding process. In most modern cultures there exists a set of similar commands, out of which the translator chooses - as a ready-made sentence - the one corresponding to the command in the original, thus choosing a sentence as a whole for the concrete act of translation. Therefore in these cases, as in the case of idioms, the UT is also a whole sentence.

\section{The question of text as a UT}

We come now to the question of whether a text as a whole is ever used as an indivisible unit for re-coding in another language, that is, whether a text can function as a UT. If we are prepared to use the term in the sense in which it was introduced, then for most cases the answer will of course be No. To justify a positive answer, a text will have to be idiomatic with regard to the meanings of its composite sentences, which is never the case.

Or practically never. There are texts whose meaning is something more than just the sum total of the meanings of its parts. They are texts of poetry, but not just any poetry, but the realest of all real poetry.

Any good poetry is, for well-known reasons, the most difficult object for translation. But where the talent of the translator is commensurable with that of the author of the original verse (the wording belongs to the well-known writer and historian J.A.Gordin) the translation of poetry may be fairly successful. Consider, for example, J.Brodsky's translation of a poem by one of the best metaphysical poets Andrew Marvell. (The poem is a fairly long one, containing fourteen quatrains. For reasons of economy we will take the first five of them.) 


\section{Eyes and Tears}

by Andrew Marvell

How wisely Nature did decree

With the same eyes to weep and see!

That, having view'd the object vain,

They might be ready to complain.

And, since the Self-deluding Sight,

In a false Angle takes each hight;

These Tears which better measure all,

Like wat'ry Lines and Plummets fall.

Two Tears, which sorrow long did weigh

Within the scales of either Eye,

And then paid out in equal Poise,

Are the true price of all my Joyes.

What in the World most fair appears,

Yea even Laughter, turns to Tears:

And all the Jewels which we prize,

Melt in these Pendants of the Eyes.

I have through every Garden been,

Amongst the Red, the White, the Green;

And yet, from all the flow'rs I saw,

No Hony, but these Tears could draw. , etc.

This is something that, one hopes, every reader will consider a very good translation. Let us now take a close look at how it is done. Note that from the very first lines the reader is plunged, as it were, into the language of the baroque culture. Note also that the original text contains many instances of the classical device of the metaphysical school, the conceit, which is defined by H. Gardner as "a comparison whose ingenuity is more striking than its justness" (Gardner, 1966: 19). In the translation all these instances are carefully preserved and finely rendered: see lines 5-8, 10-12, 17-20, where in some cases the very wording of a conceit
Из Эндрю Марвелла

ГЛАЗА И СЛЕЗЫ

Сколь мысль мудра Природы - дать

Глазам рыдать и наблюдать,

Чтоб, вещь найдя ничтожной, глаз

Мог жалобу излить тотчас.

Но Зренье, льстя, углы не те

Находит в каждой высоте;

Слеза ж-и под углом небес

Верна, как водяной Отвес.

Так, скрупулезно взвесив груз

Двух слез во влажных Чашах, Грусть,

Дав замереть им наравне,

Оплачивает радость мне

Bсе то, что ценит Мир и чтит

Как ценность Ювелир, блестит

Слабее, говоря всерьез,

Чем длинные подвески слез.

Среди Цветов бродя любых,

Из Алых, Белых, Голубых

Я чашечек, склонясь, впивал

Не Мед, но Слезы добывал - $u$ m.д.

is reflected, especially in lines 5-8. Then there are some classical examples of lexical transformations. There is also a comparatively free version of lines 13-16 (actually, the weakest portion of the translation with its rather helpless intrusion of говоря всерьез in line 15). Still, the deviation from the literal original in lines 13-16 is done within the traditionally accepted limits. All in all the Russian text is an excellent example of what a good translation of poetry can be.

Now consider J. Brodsky's translation of a poem by another of the metaphysical poets - by the greatest of them all, John Donne. 


\section{The Apparition}

by John Donne

When by thy scorne, O murdresse, I am dead, And that thou thinkst thee free

From all solicitation from mee,

Then shall my ghost come to thy bed,

And thee, fain'd vestal, in worse armes shall see;

Then thy sicke taper will begin to winke,

And he, whose thou art then, being tyr'd before,

Will, if thou stirre, or pinch to wake him,thinke

Thou callst for more,

And in false sleep will from thee shrinke,

And then poore Aspen wretch, neglected thou

Bath'd in a cold quicksilver sweat wilt lye

A veryer ghost than I;

What I will say, I will not tell thee now,

Lest that preserve thee; and since my love is spent,

I'had rather thou shouldst painfully repent,

Than by my threatenings rest still innocent.

From the very first words of the Russian version the reader hears a powerful voice of a really outstanding poet. This translation reads as an indigenous Russian poetical text that can be enjoyed as such, without appellation to the original. In translating from A. Marvell the poet was obviously taking pleasure in imitating the author's similes and conceits; in rendering Donne he created a complete new piece of Russian poetry. It is, of course, a translation, but a translation that reads as an original. Although A.Marvell was much younger than J.Donne (when Donne died Marvell was ten years old), the text of Посещение reads as if it was written centuries later than Глаза и Слезы - almost as a modern poetry. Where in the translation from Marvell we can compare line after line of the SL text with the lines in the translation, here even the number of lines in the two texts does not coincide: the Russian text contains one line the more.

In the original text the author uses an occasional shorter line, which gives the text
Джон Донн

\section{ПОСЕЩЕНИЕ}

Когда твой горький яд меня убьет,

Когда от притязаний и услуг

Моей любви отделаешься вдруг,

К твоей постели тень моя придет.

И ты, уже во власти худших рук,

Ты вздрогнешь. И, приветствуя визит,

Свеча твоя погрузится во тьму.

И ты прильнешь к соседу твоему.

А он, уже устав, вообразит,

Что новой ласки просишь, и к стене

Подвинется в своем притворном сне

Тогда, о бедный Аспид мой, бледна

В серебряном поту, совсем одна,

Ты в призрачности не уступишь мне.

Проклятия? В них много суеты

Зачем? Предпочитаю, чтобы ты

Раскаялась, чем черпала в слезах

Ту чистоту, которой нет в глазах.

additional powerful stroke (see lines 2, 9 and 13). The translator uses an analogous device, namely, setting a line as a separate paragraph - but not necessarily in the parts of the text which are semantically parallel to the shortened lines of the original. He does it where it suits his own text (see lines 4, 8 and 12).

When this translation was published, it was done not as it is done here, in parallel texts, where lines are presented so as to make easy the comparison of the texts. In the linear structure of the text of translation there is a truly Brodskian visual interval before the final, concluding quatrain, - something that is absent in the original. True, there is, in the original, an indication of a similar intonation break before the final quatrain, but this is achieved through the difference in length between the very short last line of the preceding quatrain and the lines that are its immediate neighbours. In the translation this line is equal in length with the preceding and following lines, which puts it on an equal footing 
with the surrounding parts of the text. Besides, the text of the final quatrain of the translation is in its wording different from what is literally said in the original. As a result, the message of the final quatrain may seem to have no logical connection with the text immediately preceding it. This impression, however, disappears with the introduction of the intonation break achieved by arranging a visual break before the concluding lines of the poem. But note that what was here done by Brodsky the translator is a device that he often used in his original verses written in Russian.

The difference in translation strategies applied to the texts by A. Marvell and by J. Donne reflects the difference between the semantic structure of the texts compared. Although A. Marvell is a fine poet considered by many to be one of the best of his school, J. Donne stands apart in the whole of English literature. In her Introduction to the collection of verses of the poets of the metaphysical school H. Gardner writes: "I have begun this volume ... with poems which in some ways anticipate the metaphysical manner: Ralegh's fine passionate conceit of a pilgrimage, ... Southwell's meditations, Shakespeare's strange celebration of married chastity ... . But the moment the reader reaches Donne, he will have the same sense of having arrived as when, in a collection of pre-Shakespearian plays, we hear the voice of Marlowe" (Gardner, 1966: 23).

J. Donne's verses are truly different from anything written at his time or later to the great extent because their meanings are never the simple sum total of the meanings of their composite sentences. The meanings of Donne's verses belong to a higher semantic/pragmatic level than a standard poetical text, even a very good poetical text. Because A. Marvell's text means exactly what is said by each of the sentences of which it is composed its translation was done almost literally sentence-by-sentence. What is more, within these sentences, as was shown above, there sometimes is an almost word-for-word correspondence between the original and the translation. In contrast, working on the translation of the poem by J. Donne the poet was confronted with a text whose meaning is something more than what is said by the sentences which compose it. As a result the translator, being himself an outstanding poet, created his own version of the text, thus virtually taking an entire text for a UT. This again brings us to the concept of an idiomatic nature of certain linguistic entities, in this case, the nature of a certain type of text.

\section{To sum up}

Unilateral linguistic units, i.e. phonemes (graphemes), which possess no meaning of their own, may function as UT, but only in cases where the corresponding fragment of the SL text is also meaningless for the recipient of the TL text.

For cases of meaningful linguistic units the choice of a particular fragment of a SL text as a UT is predictable and is the function of the role of the fragment in the larger construction where it is an immediate integral part. If the fragment in question makes its own separate input into the meaning of the whole construction it should be taken as an individual object for re-coding, i.e. as the UT. If, however, the meaning of the larger construction is idiomatic with regard to the meanings of its integral parts it is the larger construction as a whole that is taken as a UT. This holds true for all and any of the meaningful linguistic entities, from morpheme to the text.

Just as smaller linguistic units, the text may also be idiomatic with respect to its composite parts, the sentences. This is something that distinguishes particularly fine poetry from other literary texts. Poetical texts characterized by this feature are entities forming their own, the highest, structural level of the whole edifice of Language. For the most part such texts are untranslatable 
because their very idiomaticity is language- and culture-specific. But in rare cases even these texts can be successfully translated - if the translator's talent is commensurable with that of the author and if the translator takes the entire text as his/ her unit of translation.

\section{References}

1. Arnold, I. V. The English Word. M.: Vysshaya Shkola, 1986. 296 p.

2. COBUILD - Collins COBUILD English Language Dictionary. London and Glasgow : Collins, 1992, $1703 \mathrm{p}$.

3. Gardner, H. Introduction. The Metaphysical Poets. Selected and edited by Helen Gardner. Penguin Books, 1966, 331 p.

4. Haas, W. "The Theory of Translation", in The theory of Meaning. Edited by R.H. Parkinson. London: OUP, 1968.

5. Ullman, St. The Principles of Semantics. Oxford : Basil Blackwell, Glasgow: Jackson, Son @ Company, 1967, $352 \mathrm{p}$.

6. Vinay, J.P and J.Darbelnet. La stylistique compareé du français et de l'anglais. P.: Didier, 1965.

7. Vinogradov, V.S. Introduction to the Study of Translation [Vvedeniye v perevodovedeniye]. M.: IOSO RAO [ИОСО РAО], 2001, 224 p., in Russian.

8. Vlakhov, S. and S.Florin. The Untranslatable in Translation.[Neperevodimoie v perevode]. M.: Mezhdunarodnyie otnosheniya, 1986, 342 p., in Russian.

9. WEUD - Webster's Encyclopedic Unabridged Dictionary of the English Language. New York.: Gramercy Books, 1989, 1854 p. 


\section{Еще раз о единице перевода}

О.И. Бродович

Институт иностранных языков Россия, 199178, Санкт-Петербург, 12 линия В.О., 13

В статье рассматривается вопрос о приниипе, на котором основывается выбор единицы перевода. Показывается, что ключевым в этом вопросе является наличие/отсутствие идиоматичности в отношениях между единицей того или иного уровня языковой структуры и той большей структурой, в которую рассматриваемая единица входит как составная часть. Если семантика более крупной структуры составляется из суммы смыслов образующих ее частей, то каждая такая часть подлежит отдельному отражению в переводе, то есть становится самостоятельной единицей перевода. Если же семантика включающей структуры оказывается чем-то бо́льшим, чем простая сумма смыслов частей, то переводу подлежит именно эта включающая структура как единое целое. Существенно, что это оказывается справедливым для единии всех знаковых уровней - от морфемы в составе слова до иелого предложения. Особое внимание уделено возможности признания текста как единицы, подлежащей цельному переводческому решению. Показано, что и к тексту применимы те же критерии, которые определяют выбор менее крупных единии перевода. Показано также, что текстами, которые могут и даже должны быть взяты как целое для перевода, являются поэтические тексты, но не любые, а лишь те, которые по своему значению являются чем-то качественно бо́льшим, чем сумма смыслов составляюших их предложений.

Ключевые слова: единица перевода, вариативность, переводческие решения, идиоматичность языковой структуры, текст как единица перевода, поэтический перевод.

Научная специальность: 10.00 .00 - филологические науки. 